\title{
Modernisation and Social Transformation in the Czech Republic
}

\author{
PAVEL MACHONIN ${ }^{*}$ \\ Institute of Sociology, Academy of Sciences of the Czech Republic, Prague
}

\begin{abstract}
The specific analysis of the Czech historical experience could offer interesting incentives for theoretical generalisations. The global post-Communist societal transformation is conceived in the following paper as a complex social transformation and modernisation in all spheres of human culture. Analogously, in several other European countries which already were relatively advanced before World War II, the influence of the totalitarian/egalitarian state socialist social system on the modernisation processes in the Czech lands was in principle negative. So far, the post-Communist transformation of Czech society has been rather successful. However, this was caused, among others, by the abandoning, the postponing, or the mitigation of some aspects of the originally presupposed radical liberal democratic changes. The long-term prospects of Czech society depend mainly on the ability of the social and institutional system to stimulate a significant progress on the road to qualitative modernisation. It will only be possible through creating a dynamic social equilibrium generating a new motivation structure based on social relationships strongly influenced by the principles of equity of chances and meritocracy.

Czech Sociological Review 1996, Vol. 4 (No. 2: 171-186)
\end{abstract}

As far as the broader theoretical and methodological background of this paper is concerned, the author will limit himself to only one short remark. The original incentive for developing the orientation of thought presented in this paper was not the academic desire to apply some already existing general theory of social change to a new historical case, i.e. the post-communist transformation of the 1990s in general or in a group of selected countries. Quite on the contrary, the considerations cumulated in this study, have been stimulated by the need to explain the concrete historical experience of the Czech and Slovak Republics with the state socialist social system, its collapse and replacement by a newly emerging social order. In the analysis of the post-Communist changes, more emphasis is given on the ongoing processes in the Czech Republic, now a sovereign state. Thus, the task of this study is to analyse, from a theoretical point of view, some aspects of the concrete historical experience of recent changes occurred in one society in the last fifty years. I do not think such an approach less valuable for the development of theoretical thought in sociology than are either the inductive generalisations of many analysed cases or the deductions on the level of abstract categories. On this point, I share one of K. Marx's methodological principles, i.e. to consider "the reproduction of the concrete by means of thought" as an indispensable, and perhaps most significant, part of theory [Marx 1857]. However, this principle can work only if the unique subject of analysis gives enough incentives for the development of theoretically relevant ideas.

I think that focusing on the Czech experience could fulfil this requirement. Before World War II, the Czech Lands belonged to advanced European capitalist industrial re-

*) Direct all correspondence to: Doc. PhDr. Pavel Machonin, DrSc., Institute of Sociology, Academy of Sciences of the Czech Republic, Jilská 1, 11000 Praha 1, phone + 4222422 09 79, ext. 311, fax + 422242202 78, e-mail machonin@mbox.cesnet.cz 
gions, with a corresponding cultural level and a well operating pluralist democracy. After the war, however, they also became a part of a small amount of countries where, in the course of a radical left-turn, the Communist attained a relatively broad social and political support and where, subsequently, the Communist policy was carried out in highly radical forms and with serious consequences on all spheres of human life. This specific contradiction brought some unique traits into the mutual relationships of social and political changes on the one hand, and of the cultural modernisation processes on the other. It became clear for the first time during the inspiring attempt at a modernising reform of the state socialist system in the 1960s, which peaked in the 1968 Prague Spring movement. The brutal defeat of this attempt caused a prolonged and harsh repression and societal stagnation in the period of 'normalisation', 1970-1989. After the 1989 'Velvet Revolution', the contradictory development continued. In none of the other post-communist countries in Europe, did the newly established political and economic system seem so radical and persistent in the endeavour to push through a liberal economic reform and corresponding right-wing orientation. This paper has been written in the time following the dramatic June 1996 Czech elections, which yet again surprised with its partial leftturn, not expected by most foreign observers. Basically, the historical developments of Czech society in the last sixty years were extremely contradictory and involved many sudden, abrupt and radical societal shifts related to the main subject of this paper: the relationship between changes in social structures and the dynamics of the modernisation (or anti-modernisation) processes. This could be the case when historical experience accumulated in one subject should bring important incentives for theoretical generalisations is one example.

\section{Basic Concepts}

The existing conceptual framework, familiarly used when dealing with social transformation and modernisation, is far from being unambiguous. There exists, e.g., a tendency to confuse the two basic concepts: social transformation and modernisation. In order to avoid possible misunderstandings, I therefore consider it useful to begin with a clarification of the most important concepts as I understand them. Looking for inspiration mainly in classical sociological and cultural anthropological works, I share the view that every human society can be conceived as a complex of three basic, mutually interpenetrating entities. These entities (leaving aside the interpenetration of society with both external and internal nature) are: a) human personalities, b) their mutual, that is social relationships and c) the culture created by them in the course of human history. Continuing the tradition of some classics of cultural anthropology and some of the pioneers of Czech sociology (Chalupný, Bláha) I apply here - in spite of the existing strong tendency to reduce culture only to 'that what people are learning, not to that what they are doing and creating' [Keesing, Keesing 1971] - the concept of culture in its broadest sense, i.e. including all creative and reproductive human activities and also all their socially adopted products - both material and non-material.

Those, however, who prefer a different concept such as A. Weber's dualism of (material) civilisation and (spiritual) culture, for example, can simply replace the concept of culture I am employing with an image of an intrinsically contradictory complex of spiritual culture and civilisation. In such a framework, the field in which social relationships and culture interpenetrate is the sphere of institutions conceived as stabilised patterns of social interactions or, concurrently, as the cultural aspect of social relationships. 
With regard to social transformation, I have in mind the historical process of a structural, qualitative change of social relationships, while in the case of modernisation, I refer to a certain orientation of structural change in culture, including institutions and corresponding socially adopted values and forms of behaviour. Those institutional changes, which are usually presupposed to be part of post-Communist transformation, e.g. the marketisation of the national economy, the introduction of a pluralist democracy and 'state of law', the creation of a balanced and stimulating structure of (predominantly private) ownership forms, etc., represent in this conceptual framework the connecting link of both major processes in question. They can be regarded, on the one hand, as changes in social relationships and on the other, as phenomena characterising modernisation in the cultural sphere.

Only the complex of cultural changes - mainly the modernisation processes - and of changes of social structures, that is social transformation (encompassing changes in economy, political relationships, law, moral, etc.), intermediated by the connecting link of institutional changes, represents the global societal transformation. And the interactions of cultural changes (modernisation) and social transformations create the societal environment for the development of human beings as social actors and personalities. In the end, the existence of rather stimulative or inhibitive conditions for the developments of human personalities is the decisive criterion for the success or failure of societal transformations.

Among the enumerated concepts, perhaps the concept of modernisation is the most disputable. I, of course, share the emphasis laid by most modernisation theories on the processes of innovation, rationalisation, mobilisation, secularisation and other kindred cultural changes. However, in our context, we were obliged to conceive modernisation as a general process embracing - including the corresponding institutional changes - each important sphere of societal life: ecology, demographic behaviour, health-care, education, science, technology, infrastructure, housing, amount and qualitative standards of production and services, well developed markets of goods, services, labour and capitals, corresponding characteristics of consumption, structure of leisure activities, advanced pluralist democracy and rationalisation of administration, perhaps quality of life of individuals and families in general. Hence, by modernisation I mean general progress in the level of broadly conceived culture. It is, of course clear, that the empirical information concerning the processes of modernisation in one country, or in a group of countries, presented in this paper, has had to be substantially reduced to only several phenomena of crucial significance for societal change.

On the other hand, the former state socialist countries' cultural backwardness in comparison with the advanced countries compelled us to exercise extreme caution with some of the consequences of so-called 'post-modernist' approaches. For the time being, we are not concerned so much with the 'pathology' of modernity (clearly a very important phenomenon occurring in the more developed countries and, unfortunately, in the future very likely to appear in our countries), as much as by the apparent lack of modernity and by the specific pathology behind it. We have also observed some post-modern phenomena in our society - partly in real social life, partly as an anticipation of possible future developments. I find it rational to make a distinction between those which only represent a little excessive reaction to the 'pathology of modernity' and those which can be explained as a comprehensible negation of the deviations and imperfections typical of the 
former phases of modernisation. Similarly, as the recently emerged stream of neomodernism referred by Alexander [1994] I, though for other reasons, view some of the phenomena stressed by post-modernists (e.g. the new role of information systems and mass media, the collapse of 'great theories' in their ideologised form, or the increase of the significance of subjective actions of individuals, social groups and institutions) rather as elements of continuing modernisation, bringing society closer to the post-industrial phase of development. I prefer to speak of a new, more complex and sophisticated phase of rational approaches to societal reality rather than of the collapse of rationalism. Perhaps, for other societies, it is time to speak about the 'end of history' (although I personally doubt it too), but in our case the very clear standards of an advanced modern society still lie before us.

Under the given circumstances, Prof. Zapf's straight-lined approach, directly linking modernisation and post-Communist transformation stressing on innovation, massconsumption, marketisation, the welfare-state, ecology, a well-operating pluralist democracy and similar well known phenomena as constituent elements of modernisation processes, seems to be quite appropriate [Zapf 1994; Machonin 1996b]. Perhaps we will also be able in the future to accurately appreciate the significance behind the sophisticated concept of 'reflexive modernisation' [Giddens 1990; Beck 1993].

\section{Communism and Modernity}

Many European - including Czech - members of the cultural 'vanguard of modernism' of the 1920s identified themselves to some degree with the Communist ideology under the assumption that this is, finally, a scientific theory aiming at the introduction of rationalism, technological progress, new lifestyle and other attributes of modernity into societal reality. This assumption also became one of the factors assisting to gain the support of a not negligible part of the Czech democratic intelligentsia in favour of the post-war Communist programme describing the idealised 'specific Czechoslovak road to socialism'. In the 1960s, yet again, a part of intellectuals met with sympathies the attempt to link the vision of the 'scientific-technical revolution' with expected reforms of the state socialist system. And even now, there are authors finally considering in their retrospective analyses some aspects of the socialist industrialisation and corresponding changes in the way of life of the Czech population under state socialism as a contribution to the modernisation processes. As all these phenomena registered in the Czech milieu have some analogies in other East-Central European countries, it is important to understand at least the main reasons for the emergence of these illusions about the modernisation potential of communism and to confront them with historical facts.

In my opinion, one of the reasons for the possibility to identify communism, or at least some aspects of its ideology and practice, with modernity, lies in the doubtless ambiguity of this social and political movement and ideology. Marxism was born in the last century as a continuation of rationally argued and presented tendencies of thought connected with the Enlightenment and bourgeois democratic revolutions, applied scientific methods of empirical cognition and building of theory and tried to base even its utopian futurological ideas and political radicalism on the presupposition of the actually ongoing industrial modernisation of technology and rationalisation of economy. Everywhere the social and political movements influenced by Marxism had to face either the backwardness of pre-industrial societal conditions or the monopolistic, authoritarian and militaristic 
tendencies of the developed capitalism (mainly those connected with the fascist ideology and politics), they emphasised the 'modern' aspects of their ideologies.

This was apparent particularly in those countries which, under objectively given pre-industrial conditions, really had to solve the tasks incurred by the first extensive phases of industrialisation and urbanisation. In some of these societies, the communist regimes in fact stimulated cultural changes crucial for modernisation and favourable for the population in certain aspects. Besides the relative technological progress in the production of goods and the basic consumption standards (including some improvement in housing conditions), a doubtless educational expansion also needs to be mentioned. It is still obvious: the less industrially developed were the post-Communist European countries before the establishment of state socialism, the stronger seems to be the 'legacy of Communism' - the positive evaluation of the 'contributions' of Communism, etc., in the public opinion and, consequently, the support in favour of political subjects linked to the communist past or using populist and authoritarian ruling methods. This historical cultural difference seems to be one of the grounds for the partly diverging public opinion and political development in the Czech Lands and Slovakia.

However, the communist regimes introduced in the European countries concerned new social systems based on the combination of totalitarianism, abolition of the market economy and subsequently the egalitarianism concerning the distribution of wealth, official incomes and, to some extent, also of lifestyles. Functionally interconnected material privileges for the nomenclature and an extensive network of corruption of the less qualified and less efficient people were inevitable. Power and income distribution became incongruent to education, work complexity and cultural level of lifestyle. A deep status inconsistency became a typical characteristic of the state socialist social structure.

Table 1. Rank Correlation Matrices for Status-Forming Variables in $1984^{*}$

\begin{tabular}{lcccccccc} 
& \multicolumn{3}{c}{ Czech Republic } & \multicolumn{4}{c}{ Slovak Republic } \\
Variables & CA & EA & MP & WC & CA & EA & MP & WC \\
\hline ED & 0.49 & 0.19 & 0.34 & 0.62 & 0.56 & 0.21 & 0.31 & 0.64 \\
WC & 0.37 & 0.20 & 0.31 & & 0.46 & 0.24 & 0.31 & \\
MP & 0.16 & 0.30 & & & 0.18 & 0.30 & & \\
EA & 0.08 & & & & 0.11 & & & \\
\hline
\end{tabular}

*) $\mathrm{ED}=$ education, $\mathrm{WC}=$ work complexity, $\mathrm{MP}=$ managerial position, $\mathrm{EA}=$ earnings, $\mathrm{CA}=$ cultural level of leisure activities. Data from the secondary analysis of results of the survey on class and social structure, IPhSo CS AS, Prague [Machonin, Tuček 1994].

The low values of correlations between the earnings distribution and other status-forming variables are particularly apparent when comparing the relationships found out both in the course of the Czechoslovak reform attempts in 1967 and in the course of the postcommunist transformation in 1991, 1993 and 1995. The somewhat higher degree of status consistency in Slovakia proves the already mentioned various modernisation impacts on the regional processes of modernisation with different levels of industrial developments on the advent of communism.

Under such conditions and after the exhaustion of natural sources caused by extensive industrialisation, the population of state socialist countries lost their motivation. People were not able to own the fair results of their work, could not be recompensed 
according to their real merits, lacked the opportunity of free development in the economic and political sphere, disposed of limited chances of free development in their leisure activities, were neither able, nor willing and, additionally, not allowed to overstep the threshold separating them from the more demanding activities typical of the intensive phase of industrial developments. Even the most developed European state socialist countries were not successful in starting the post-industrial developments on a large scale. Only the limited sphere of production, research and development connected with the military purposes could be considered an exception. At the same time, the arms production was one of the reasons which led to the extreme and extensive industrialisation favouring heavy industry and thus contributed to the stagnation of the acquired extensive industrial level. Compare analogous conclusions in Srubar [1991].

While in the originally pre-industrial countries the state socialist way of industrialisation can be said to have somewhat contributed to the basic modernisation of societies concerned - although in specific forms of the 'Soviet-type industrialism' -, the same cannot be said about some of the countries which belonged to the economically and culturally relatively advanced European states before the Second World War. This is doubtlessly valid for the Czech Lands, for East Germany and probably for Slovenia too.

The difference between the two clear-cut types of developments (from both the pre-industrial and industrial level) can be demonstrated using the cases of the Czech Lands and Slovakia. We will use two of the basic indicators of degree of modernisation: the branch (sector) structure and educational attainment.

Table 2. Branch Structures in Percentage of Economically Active Persons*

\begin{tabular}{lllllllll} 
& \multicolumn{4}{c}{ Czech Lands } & \multicolumn{4}{c}{ Slovakia } \\
Sector & 1921 & 1930 & 1983 & 1992 & 1921 & 1930 & 1983 & 1992 \\
\hline Agriculture & 36.6 & 30.4 & 11.2 & 8.6 & 65.0 & 60.6 & 17.2 & 12.1 \\
Industry & 46.2 & 47.6 & 55.3 & 49.1 & 20.9 & 20.7 & 49.8 & 44.0 \\
Services & 17.2 & 22.0 & 33.5 & 42.3 & 14.1 & 18.7 & 33.0 & 43.9 \\
\hline
\end{tabular}

*) Recounted statistical data from [Machonin 1996a].

Table 3. Attained Levels of Education in Percentages of Population over 15 Years*

\begin{tabular}{lrrrrrrrr} 
& \multicolumn{3}{c}{ Czech Lands } & \multicolumn{3}{c}{ Slovakia } \\
& \multicolumn{2}{c}{ Males } & \multicolumn{2}{c}{ Females } & \multicolumn{2}{c}{ Males } & \multicolumn{2}{c}{ Females } \\
& 1950 & 1991 & 1950 & 1991 & 1950 & 1991 & 1950 & 1991 \\
\hline Tertiary & 1.6 & 9.5 & 0.3 & 5.2 & 1.0 & 9.5 & 0.1 & 6.3 \\
Secondary & 7.3 & 21.7 & 3.2 & 24.6 & 4.6 & 22.1 & 2.0 & 26.9 \\
Lower degrees 91.1 & 68.8 & 96.5 & 70.2 & 94.4 & 68.4 & 97.9 & 66.8 \\
\hline *) Recounted statistical data from [Machonin 1996a].
\end{tabular}

This, as well as many other known data, clearly shows that in the end the extensive development under state socialism brought the industrially more advanced Czech Lands (now a sovereign country) only very limited pro-modernisation changes in comparison with the pre-industrial Slovakia. Even the quantitative development of the educational structures was substantially more favourable for the latter. It is necessary to take into account that most quantitative and qualitative indicators of the Czech post-war modernisa- 
tion processes lag significantly behind analogous indicators for comparable Western countries like Austria, Belgium, Norway, the Netherlands, etc. It means that, in principle, the long development started in the late 1930s until the late 1980s can be evaluated from the point of view of stages of modernisation rather than of stagnation or even of relative regression.

This tendency was already perfectly known by the better educated part of the Czech population in the 1960s and has become one of the stimulating factors the reform attempts with their culmination in the 1968 Prague Spring movement. The endeavour to substitute the conflictual co-existence of capitalism and socialism by the convergence strategy was accepted in the case of this region as a) a confirmation the cultural stagnation under state socialism and $b$ ) as a challenge to start the trend of a new stage of modernisation [Machonin 1992]. Unfortunately, the Warsaw Pact occupation and the reestablishment of the nomenclature-rule not only renewed the operation of the totalitarian and egalitarian inhibitive mechanisms known from the 1950s, but additionally, required the strengthening of the social corruption benefiting the numerous less qualified strata as a compensation for the loss of national sovereignty.

After the sudden and smooth collapse of the state socialist regime in 1989, the stagnation of modernisation processes expressed itself a) in the radical turn of the intelligentsia from the Communists to those forces which were supposed to re-fuel the modernisation strategies and b) in the consequent popularity of the slogan 'return to Europe' understood as an attempt to join the advanced European countries.

Generally speaking, one cannot only speak about the 'interrupted modernisation' (Mojca Novak's formulation for Slovenia), as far as the Czech case is concerned, but more directly about - for the second time - a repeated dysfunctional extensive industrialisation with final anti-modernisation effects. The decisive reason for this - after the influence of the German occupation and the consequent inclusion of the Czech Lands into the military economy during the Second World War - was, indeed, the protracted influence of the state socialist social order. From the point of view of the Czech experience, the state socialist system as the 'really existing' incarnation of the Communist ideology and policy, proved to be anti-modern right through its essential characteristics. This circumstance became one of the most important reasons for the simple and easy collapse of communism in the Czech Lands. One of the leading presupposition of the country's development after the 'Velvet Revolution' was, for a large part of the population, the return to European modernisation trends and, as a goal, the attainment of modern standards of advanced countries.

\section{Achievements and Problems of the Czech Societal Transformation}

Leaving East Germany aside, which represents rather a case of the national reintegration based on the more developed part of a formerly divided country, there remain four countries in East Central Europe of the so-called Visegrád group. After the well-known leftturns in Poland and Hungary and the conflictual developments on the Slovak political scene, it is quite clear that the original, somewhat simplified one-way models of liberal democratic transition, popular after 1989, have not been satisfactorily verified by the societal changes in these countries. It does not mean that the post-communist transformation has been abandoned there. The real changes have been much more complicated and conflictual than initially expected. 
Before the June 1996 elections, the Czech Republic was considered by its government and also by many both domestic and foreign observers as, perhaps, the only case among the Visegrád countries where nearly all principles of the transition models had been applied and where successful results had been attained. Some of these achievements are commonly known and doubtless:

a) Obvious was the progress in the field of human and citizens' rights with broad social support for a liberal democratic President and a relatively broad social support for the right-wing conservative-liberal government. (Even after the last elections it still embraced approximately half of the adult population.)

b) An extensive privatisation and substantial liberalisation of the national economy was attained in conditions of a stable macro-economic balance and the annual inflation has been reduced to one-figure percentage.

c) Quite clear was the progress of the service sector which in 1994 supplied 54\% of the GDP, that is much more than in the over-industrialised state socialist economy.

d) Some recovery and even revitalisation of the economy was observed. After the initial fall of the GDP in 1991 to approximately $82 \%$ of the level achieved in 1989, this indicator grew gradually in the last years, already stepped over the level of the late 1980s and is still increasing today.

e) In 1991 and after the decrease of the average real income to three quarters of their value in 1989, this indicator already stepped over the initial level and is making yearly progress. These changes were followed by a steadily low unemployment rate between 3 and $4 \%$ and nearly negligible poverty rate.

f) As indirect consequences of some of the transformation processes, several improvements were shown in the environmental parameters and even in the life expectancy.

On the other hand, social changes accompanying all the above-mentioned achievements were not favourable and smooth for everyone in all parameters.

An almost complete exchange of the old 'nomenclature' for a new political élite led to the stepwise and simultaneous exclusion not only of the Communists from 1989, but also of moderate centrist and left-wing democratic subjects, including many of those active in the anti-Communist dissent and including the non-communist Social Democracy, from the power élite. In spite of the mentioned progress made by pluralist democracy, this kind of changes also led also to the emergence of some centralist, bureaucratic and partocratic tendencies, hindering the developments of 'civil society'. These became the subject of a systematic criticism by the President of the Republic [Havel 1996]. One of the results of the June 1996 elections will obviously be distinct improvements in this direction.

The far-reaching and rapid privatisation of the Czech national economy accomplished either by the voucher method, or by the standard privatisation methods have not yet led to firm and clear-cut ties between the new owners and managers - mostly prepared for their careers during their professional experience in state socialism - and have left relatively high participation of the state (through its share in the large banks and companies) in the formally privatised economy [compare Mlčoch 1995a, b]. The financial capital, including the investment funds and companies, has remained one of the most probable pretendents of the leading position in economy, while the decisive role of managers is not as clear as I. Szelényi assumes on the base of the Hungarian experience 
[Szelényi 1995]. Besides, a part of the privatisation acts and initial activities of the privatised firms have been doubtlessly accomplished by unlawful and/or immoral means.

The so far accomplished differentiation of incomes, wealth and life-styles created a stratification structure with some class aspects. Approximately $10-12 \%$ of the economically active population belong now to the higher income categories (with significantly higher representation of entrepreneurs with employees, small private businessmen and a section of higher professionals), while the agricultural workers and members of cooperatives, the unskilled and semi-skilled workers as well as some pensioners and members of the one-parent families and families with three and more children, often belong to the segment of population endangered by poverty. Some surveys show that the amount of families having certain difficulties with ensuring their elementary needs could be estimated as approximately one quarter of the total number.

However, the cross-national comparisons prove that the inherited, still relatively egalitarian distribution of incomes continues to operate: among one half of the population was registered in 1992 in the medium interval of an equidistant seven degrees scale of per/capita family incomes, which is more than in Hungary and much more than in Poland. The average ratio for one hour's wage of an employee with tertiary education to the wage of a worker with elementary education and without apprenticeship or vocational school in 1994 was not greater than $1.7: 1$. In 1995 the ratio among males was $1.95: 1$ and $1.7: 1$ among females.

It is no wonder, under these circumstances, that the President of the Union of Industry and Transport (that is the head of the main industrial lobby) Mr. Š. Popovič explained its position in this issue with the following surprisingly open words:

"In the former regime, you earned roughly the same, irrespectively of whether you were working or not. That is why after the revolution all applauded the idea that the social differences among people would finally be more distinct. Now some social stratification has appeared. And some people wish that everybody were paid the same once again. However, I cannot agree with this, it is a very dangerous tendency. This would lead to the thought that stealing is better than working more and better. Such an approach does not motivate people to a better achievement but to destruction." [Popovič 1996a]

The most complicated issue resides in the situation of the "new (upper and lower) middle classes' composed of higher and lower professional employees. These groups are developing slowly and unevenly. The status of manager in industry, particularly if employed a firm with foreign capital, other economic professionals, mainly in the business services (banks, insurance), professionals in the foreign trade, information services, communications, mass-media and entertainment industry, in some sections of administration, justice, armed forces are particularly advantageous. However, the material status of most physicians and other professionals in the health-care and social services, teachers of all levels, workers in science, research and development, people active in culture and arts and in kindred professions is, as a rule, far from being satisfactory. If we add the relatively good situation of some branches of heavy industry with their lower than average qualification level, it is clear that the differentiation in wages is far from matching the differentiation in work-complexity and qualification. 
Table 4. Average wages in selected branches in 1995 in thousands CZK

$\begin{array}{lrlr}\text { Credit plus insurance } & 18.7 & \text { Research and development } & 9.0 \\ \text { Finance } & 14.3 & \text { Construction } & 8.8 \\ \text { Information services } & 12.5 & \text { Motor-cars production } & 8.3 \\ \text { Insurance } & 12.1 & \text { Machinery } & 7.9 \\ \text { Energy } & 10.4 & \text { Health-care } & 7.5 \\ \text { Coal-mining } & 10.3 & \text { Education } & 7.4 \\ \text { Publishing and press } & 10.1 & \text { Culture, recreation, sport } & 7.1 \\ \text { Administration, defence } & 9.6 & \text { Agriculture } & 6.9 \\ \text { Metallurgy } & 9.4 & \text { Textile industry } & 5.9 \\ & & & \end{array}$

The unfavourable situation of numerous groups of professionals with tertiary and secondary professional education not only hinders the development and homogenisation of the middle-classes, so important for the maintenance of social equilibrium, but, concurrently, also hinders the implementation of the meritocratic principle, conceived as social equity of chances.

The contemporary class structure as well as intertwining with the social stratification of the Czech society is not distinctly enough developed or stabilised yet. It represents rather a dynamically moving hybrid combination of surviving state socialist (etatist and egalitarian) principles of social differentiation with emerging new social differentiation (class structure and social stratification) typical of modern industrial and post-industrial societies.

The increase of vertical social differentiation has had a significant impact on the attitudes and political orientations of people. At present, the Czech population's opinion of the post-Communist transformation is far more sceptical than it was at the beginning of this process. It is becoming more and more socially differentiated according to the acquired social experience. All this is contributing to the gradual increase in the social determination of political orientations, preferences and voting behaviour. As a result, a long-term polarisation process was observed even before the 1996 elections between the two right-wing civil parties and the Czech Social Democracy.

Table 5. Ratio of Votes or Voting Preferences for the Civil Parties and for the Social Democracy

\begin{tabular}{|c|c|c|c|c|}
\hline \multirow{2}{*}{$\begin{array}{c}\text { Elections } \\
1992 \\
\end{array}$} & \multicolumn{3}{|c|}{ Public Opinion Polls* } & \multirow{2}{*}{$\begin{array}{c}\text { Elections } \\
1994 \\
\end{array}$} \\
\hline & $9 / 92$ & 9/95 & $5 / 96$ & \\
\hline $4.28: 1$ & $6.00: 1$ & $1.33: 1$ & $1.26: 1$ & $1.15: 1$ \\
\hline
\end{tabular}

In the Czech case, this turn is not favourable for the direct followers of the Communist Party, but for the traditional left-centrist Social Democratic Party. Up to now it has not been as extensive as the recent left-turns in Poland and Hungary and did not bring the victory of a new, relatively homogenous majority. However, it is an ongoing left-turn, indeed, which in some points corroborates the Polish and Hungarian experience.

Thus we come to the conclusions concerning the often declared specific Czech transformation. The transformation process in the Czech Republic in some points really 
differs from the changes in the other three Visegrád countries. It has been more moderate and less conflictual.

The main factors delaying so far a sharp culmination of the social and political conflicts in the Czech Republic and an even more radical left-turn, in our opinion, are: a) a better economic situation at the beginning of the transformation; b) the initial political situation which was in a way also more favourable for the post-communist transformation, namely, a high degree of discreditation of the Communist Party; c) a more careful course of action of the Czech right-wing governments in the process of economic and social reforms; d) the notorious historically developed high adaptability of the Czech people to sudden social and political changes.

On the basis of these conclusions we can state that the post-Communist changes in the Czech Lands have been so far relatively successful. Indeed, they seem to be, in many ways, closer to what was expected from the original transition models, than what happened in other countries (except East Germany. These results were however achieved by abandoning, or, at least, with the substantial mitigation of the formerly presupposed economic shock-therapy as well as of some imaginable hardships in the political field. Particularly in the field of the widely conceived social policy, a careful approach led by all governments in the period of post-Communist transformation moderated the conditions created by economic reforms, mainly for the lower classes. On the other hand, the processes of meritocratisation were hampered to the dissatisfaction of the new middle classes. In this way, many immediate achievements occurred despite the fact that the solution of many problems was at the same time postponed for future phases of development or were solved to the dissatisfaction of a not negligible part of the population. This experience influenced the results of the 1996 elections, an event which has meant some shift in the political power distribution, by now closer to the standard equilibrium of the democratic right-wing and left-wing political parties as seen in advanced European countries.

As far as the future developments in the Czech Republic are concerned, one cannot totally exclude the eventuality of partial success of either the left-, or rather the rightwing variants of authoritarian populism, although this eventuality has so far remained unlikely. However, the basic meaning of post-Communist transformation can be achieved only by the realisation of the democratic and market (liberal) alternative of development in any one of its possible variants. So far, the most likely perspective for the Czech Republic in the next years still consists in the continuation of the neo-liberal strategy of transformation, perhaps with some modifications coming from the centrist liberal democratic strategy and from the pressure of the social reformists. Less probable, but not fully excluded, seems to be the social reformist variant of the liberal democratic alternative of changes (in possible combination with the socially coloured centrist liberal democratic strategies). In certain circumstances, even a 'large coalition' involving social and political subjects from the democratic left-centre to the neo-liberal right would not be excluded, although this solution does not seem likely in the actually existing present conditions.

\section{Long-Term Prospects: Post-Communist Transformation and Modernisation}

The brief analysis of the social and political strategies of post-Communist transformation presented in the previous section is significant mainly in a short- or medium-term perspective. If any one of the enumerated liberal democratic strategic orientations win within the next two or four years, or if any combination of these strategies succeeds, it is quite 
clear that only some important institutional and corresponding social changes could be completed or newly concretised in this short-term.

However, even the most imaginable radical institutional and social transformation following the neo-liberal concepts would in no case mean the fulfilment of the essential long-term goals which many people quite naturally connect with the post-communist societal transformation in East-Central Europe and, especially in the Czech Lands. The long-term prospects of the Czech developments can only be discussed essentially in the framework of a completed conceptual apparatus, encompassing the crucial issue of mutual relationships between post-Communist social transformation and modernisation.

Many social scientists (Habermas, Zapf, Offe, Srubar, Müller, Havelka and others) have stressed the importance of the modernisation processes in the post-communist changes. Most authors dealing with these issues quite rightly evaluate many of the steps already accomplished or in the process of being accomplished in the rebuilding of social institutions as modernisation measures. This concerns the introduction of both the parliamentary democracy and state of law and the market institutions and instruments as well as many other reforms. However, the profound sense of the 'escape from state socialism' does not consist only in the revolutionary or reform changes in (selected) institutions, mainly those regulating the distribution of power, incomes and wealth. (Compare with the identical position of P. Sztompka concerning the same issue [Sztompka 1996].) It was quite natural, that this kind of institutions has become the primary subject of rebuilding in the course of and after the political upheavals. On the other hand, if one of the most important reasons for the collapse of Communism was the population's objectively determined dissatisfaction with the quality of life as a whole (from lack of freedom through stagnation of living standards, short life expectancies and deterioration of the environment to low standards of work productivity, technological level of production and insufficient information services), then the modernisation of the key political and economic institutions will demonstrate its usefulness only if it gives incentives for positive changes in the whole quality of life as well. That is why we are compelled to conceive modernisation as a long-term process of profound changes in all spheres of culture, the success or failure of which have not yet been decided by the first, although highly important, steps in modernisation of a section of institutions.

As it has been already emphasised, the modernisation processes in the Czech Lands had already progressed before World War II. The analysed developments during the German occupation and the state socialist regime rule led to substantial lagging behind the advanced European countries. After November 1989, the modernisation processes in the Czech Republic progressed (concurrently with the already discussed major changes in institutions) mainly in the field of information and business-services as well as in the import of a wider selection of consumer goods. Some positive quantitative changes are visible also in the educational system, particularly as far as the secondary professional and tertiary education is concerned. However, the modernisation is still lagging behind West-European standards in science, research and development, many qualitative aspects of education, technological progress and restructuralisation on the level of enterprises, health-care, housing, consumers' satisfaction and protection, environmental protection, culture, the rationalisation of administration, etc.

At least two of the broad spectre of the problems connected with the insufficient modernisation need to be especially mentioned here. First of all, an increasing number of 
both foreign and domestic economists connect the well known difficulties in the Czech foreign trade balance (increasing prevalence of import of goods above export) with still low levels of technology and labour-productivity on the micro-level of industrial enterprises, that is with the lagging behind of the restructuralisation of plants and enterprises. Many of these experts explain this phenomenon with the insufficient degree of the privatisation process. Let me once again use one of the declarations of the 'industrial lobby's' leader. Having been asked about the reasons of the low unemployment rate and the existing 'lack of skilled people', he simply stated:

"The main restructuralisation of enterprises has not yet been accomplished. It is true, they have been privatised, but the former over-employment is still there. (...) The enterprises have often remained the same as they were in the past. The coupon privatisation has been carried out, but the new owners have brought neither new money, nor unfortunately, new ideas about what to do with the firms. (...) However, the restructuralisation can be carried out only by really existing owners." [Popovič 1996b]

Another frequently presented explanation of the same phenomenon resides in emphasising the lack of young professionals with scientific and/or technological qualification capable of elaborating and realising modern scientific and technological projects [Janouch 1996]. Directors of many advanced machinery factories complain of insufficient 'supply' in tertiary technological schools leavers.

This explanation leads to the second important aspect of the insufficient modernisation. It is, generally speaking, the very slow and structurally unbalanced development of the quaternary sector, science, research and development and education inclusive. It has been proven by many special studies that the conditions for science, research and development are so far particularly unfavourable [see, e.g., Niederle 1994]. The most regrettable statistics about the transformation process I have ever seen, shows the decrease in the number of people employed in research and development from 138 thousand in 1989 to 39 thousand in 1994, including the decrease in workers with tertiary level education from 46 thousand to 14 thousand [Statistická... 1995: 285]. Even taking into account possible lower qualification of a part of employees in the 1980s, these figures reflect a catastrophical process. This decrease has not been substituted by a corresponding increase of people engaged in research and development at universities, where conditions for such activities remained unfavourable, and unfortunately, by an increase on the soil of practically non-existing private research institutes, either. Some authors explain the difficulties of the developments in the quaternary sector by the inability of the free market instruments to saturate the demanding needs of this sector and see in the apparent state of crisis in science, research and development, health-care and culture and in the existing difficulties in education, a proof of the urgency to complement the market relationships by the operation of a strong public sector in this field [Pick 1996].

In any case, all the above mentioned issues represent crucial points deciding whether the modernisation process in the Czech Republic will be able to overstep the traditional industrial cultural level and lead to a progressive development of the already existing nuclei of the post-industrial phase of its history.

What are the reasons for the relatively slow pace of thus conceived modernisation in various spheres of societal life? The clearest reason seems to be the lack of time and financial means (in a still undercapitalised country). This could be partly connected to 
the second reason, that is the endeavour of the ruling élites to prevent eventual dissatisfaction of the lower classes with the ongoing political changes and social differentiation. In other words, it is the problem of the high social costs of the post-Communist transformation, spent at the detriment of investments put into the development of the quaternary sector (including adequate salaries) and into the restructuralisation of the industrial production and of the infrastructure. At the same time, the left-wing oriented critiques point out the wasting of public financial means in favour of people getting rich by illegal and/or immoral means. The third explanation could stress the obvious unwillingness of the Czech conservative neo-liberals to use even the market-conform means for an intentional stimulation of modernisation tendencies on the base of rational strategies concerning the development of the national economy, or, at least, of some of its branches. Thus, the 'invisible hand of the market' remains in this regard also blind.

Our survey on "Actors and Strategies of Social Transformation and Modernisation" in 1995 showed that more than $40 \%$ of the adult population express consequent promodernisation attitudes mainly concerning production, even if it were to bring some social costs (increase of unemployment, endangering of firms with obsolete technology, decrease in agriculture); about 20\% are against and the rest is neutral. [Machonin 1996c] This is not a bad result as far as socio-psychological presuppositions of modernisation are concerned.

The attitude of the decisive political subjects to the same question seems to be far more complicated. The Czech Social Democracy, naturally stressing the principle of social solidarity, concurrently devoted some passages of its programme documents to the support of individual aspects of the modernisation trends. Access to education, support of export of goods and services produced by progressive branches and companies, formulation and realisation of the 'industrial policy', improvement of the situation in the quaternary sectors and some other items of this reformist programme may be important in this connection. On the other hand, the topic of modernisation seems to be not too attractive for the right-wing parties, which almost forget to mention it in their programmes, mainly because any engagement in this direction is seen as a deviation from the programmatic non-interventionism required by the neo-liberal doctrine. However, our survey data from 1995 shows that Social Democrats sympathisers, that is their social background, are less intense supporters of the modernisation processes (if they required social costs) than people supporting the right-wing civil parties. It is a paradoxical situation: those who declare to be pro-modern have not a sufficient social support for modernisation actions since their electorate prefers social solidarity (and, frequently, egalitarianism). On the other hand, those, who receive social support for modernisation from better educated, more competent and enterprising people are not willing to take any clear-cut measures in favour of this process for ideological reasons and, in practice, are in many cases acting against it by reducing (on fiscal grounds) means necessary for the development of the budget sphere.

In any case, the long-term future depends on further, widely conceived, modernisation of Czech society. Irrespective of the results of the recent elections, all significant political and other institutional subjects have to face this challenge. It seems true that the new competition already opened after the elections will not touch only the traditional social and political problems connected with the increasing social differentiation. One of the key issues of the future social transformation will be how to achieve a dynamic social equilibrium in order to push forward the qualitative modernisation of the country. The 
only possibility is to built a new motivation structure, corresponding to a modern market society by giving new life to equity of chances for individuals, families and firms and of social justice based on rewards roughly adequate to the real achievements of all socially relevant actors, both individual and institutional ones. In the long-run only a substantial progress of meritocratic principles will give the ongoing social transformation the quality necessary for further modernisation. Despite the leading Czech right-wing political party simply refusing in its political programme the idea of social justice as a 'tragic and quite false Utopia', we are convinced that the long-term social and political strategy of significant political subjects will be evaluated mainly in terms of their capability to propose and concretise strategies able to achieve the goals of modernisation and to develop appropriate means of motivation based on the principle of equity.

PAVEL MACHONIN was the head of a team that in 1967 carried out the first representative survey on social stratification and mobility in Czechoslovakia. The results of the survey were published in 1969 in the book Czechoslovak Society. After an enforced break in research activities, he returned in 1990 to professional work in sociology. At present, he is working at the Institute of Sociology of the Academy of Sciences of the Czech Republic in Prague. He has published a new study Czechoslovakia's Social Structure on the Eve of the Prague Spring 1968 (1992) as well as a number of articles in the Czech Sociological Review, other journals and miscellanies. In the framework of an international project Eastern Central Europe 1993 he elaborated the study PostCommunist Transformation in the Social and Political Sphere in the Czech Republic. His research activities continue to focus on the problems of social transformation and modernisation in the Czech and Slovak Republics. In this field, he has prepared three recently published books.

\section{References and Literature}

Alexander, J. 1994. "Modernisation Theory after "the Transition"” Zeitschrift für Sociology 23: 165-197.

Aron, R. 1962. Dix-huit leçons sur la société industrielle. Paris: Gallimard.

Bauman, Z. 1993. Úvahy o postmoderni době [Considerations on the Post-Modern Era]. Praha: SLON.

Beck, U. 1993. Die Erfindung des Politischen. Zu einer Theorie reflexiver Modernisierung. Frankfurt am Main: Suhrkamp Verlag.

Bell, D. 1973. The Coming of Post-Industrial Society. New York: Basic Books, Inc., Publishers.

Bláha, I. A. 1968. Sociologie [Sociology]. Praha: Academia.

Chalupný, E. 1927. Sociologie, díl I, svazek 1. [Sociology I/1] Praha: Bursík a Kohout.

Giddens, A. 1990. The Consequences of Modernity. Cambridge: Polity Press.

Habermas, J. 1990. Die Nachholende Revolution. Frankfurt am Main: Suhrkamp Verlag.

Havel, V. 1996. "Projev v Poslanecké sněmovně" [Speech in the House of Representatives]. Právo 13. 3.

Havelka, M. and K. Müller 1996. "Procesy transformace a teorie modernizace" [Transformation Processes and Modernisation Theory]. Sociologický časopis 32: 143-157.

Janouch, F. 1996. "Projekt Astra 2000" [The Project Astra 2000]. Právo January 10.

Keesing, R. and F. Keesing 1971. New Perspectives in Cultural Anthropology. New York: Holt, Rinehart and Winston, Inc.

Kroeber, A. L. and C. Kluckhohn 1969. Kritický nástin systémů a definic kultury. [Culture. A Critical Review of Concepts and Definitions]. Brno: KKS.

Machonin, P. (ed.) 1969. Československá společnost. Sociologická analýza sociální stratifikace [Czechoslovak Society. A Sociological Analysis of Social Stratification]. Bratislava: Epocha. 
Machonin, P. 1992. Sociální struktura Československa v předvečer Pražského jara 1968 [Czechoslovakia's Social Structure on the Eve of the Prague Spring 1968]. Praha: Karolinum.

Machonin, P. 1996a. "Social Metamorphoses." In Czechoslovakia 1919-1992. A Laboratory for Social Change, by J. Krejčí and P. Machonin. London: Macmillan, forthcoming.

Machonin, P. 1996b. "Post-Communist Transformation and Modernisation". Slovak Sociological Review, forthcoming.

Machonin, P. (ed.) 1996c. National Report on the Results of the Survey "Strategies and Actors of Social Transformation and Modernisation” Czech Republic. Prague: ISo AS CR.

Machonin, P. and M. Tuček 1994. "A Historical Comparison of Social Structures in the Czech Republic in the Years 1984-1993”. Czech Sociological Review 2: 149-172.

Marx, K. 1857. "Úvod (Ke kritice politické ekonomie)" [Introduction (To the Critique of Political Economy)]. Pp. 659-684 in Spisy 13, by K. Marx and B. Engels. Praha: NPL.

Mlčoch, L. 1995a. "Lze považovat transformaci za uzavřenou?" [Can Be the Transformation Considered as Closed?]. Hospodářské noviny April 14.

Mlčoch, L. 1995b. "Institucionální pohled na transformaci” [The Institutional Approach to Transformation]. Hospodářské noviny April 28.

Niederle, J. (ed.) 1994. K postavení vědy a výzkumu v zemích OECD a v České republice [About the Position of Science and Research in the OECD Countries and in the Czech Republic]. Praha: AV ČR.

Parsons, T. 1971. The System of Modern Societies. Englewood Cliffs, NJ: Prentice Hall, Inc.

Popovič, Š. 1996a. "Kdo neměl a nemá skrupule, může zbohatnout rychleji" [Who Has Not Yet Had Scruples Can Get Rich More Rapidly]. Právo June 14.

Popovič, Š. 1996b. "Přidávat peníze zdravotnictví je jako přilévat vodu do cedníku" [To Give More to the Health-Care Is Like to Pouring Water into the Strainer]. Právo March 21.

Pick, M. 1996. "Konec dějin, nebo konec práce?" [The End of History, or the End of the Labour?]. Hospodářské noviny June 4.

Srubar, I. 1991. "War der reale Sozialismus modern? Versuch einer strukturellen Bestimmung". Kölner Zeitschrift für Soziologie und Sozialpsychologie 43: 415-432.

Statistická ročenka České republiky - Statistical Yearbook of the Czech Republic '95. 1995. Praha: Český statistický úřad.

Szelényi, I. 1995. The Rise of Managerialism: the "New Class" after the Fall of Communism. Budapest: Collegium Institute for Advanced Study.

Sztompka, P. 1996. "Pohled zpět: Rok 1989 jako kulturní a civilizační zlom” [Looking Back: The Year 1989 As a Cultural and Civilizational Break]. Sociologický časopis 32: 5-20.

Weber, A. 1927. Ideen zur Staats- und Kultursoziologie. Karlsruhe: G. Braun.

Zapf, W. 1994. Modernisierung, Wohlfartsentwicklung und Transformation: Soziologische Aufsätze 1987-1994. Berlin: Seismo Verlag. 